\title{
Implementation of Counseling Guidance Services on Social Ethics in Students of Class V SDN 1 Kebumen
}

\author{
Nanda Eka Saputri, Steffina Indri Hapsari, Usvah Istikomah, Moh Salimi \\ Universitas Sebelas Maret \\ nandaeka176@gmail.com
}

\section{Article History}

accepted 24/09/2019 approved 01/10/2019 published 01/12/2019

\begin{abstract}
This Research aims to identify the implementation of counseling services to the ethics of Grade 5 students at SD N 1 Kebumen 2019/2020 amounting to 39 students. This Research uses a quantitative descriptive approach with a survey method of dividing the type of closed poll in which there is an alternative answer in the form of "Yes " or "no " and a qualitative descriptive approach with data collection methods Interview to The teacher to get more information. The Research indicators of social ethics include manners, empathy, atmosphere and hangout, honesty and order. The collected Data is analyzed using the percentage analysis. The results showed that students association ethics belong to very high criteria with a percentage of 87.17\% (34 students) while the criteria are as high as 12.8\% (5 students). Conclusion of this research is the ethical Skills of Students 'Association is good because the percentage of research results is calculated high and the results of interviews with class parents on the service of $B K$ is effective. In connection with this research, counseling services have an effect on the level of social ethics in students.
\end{abstract}

Keywords: Ethics, social relations, counseling services

\begin{abstract}
Abstrak
Penelitian ini bertujuan mengidentifikasi penerapan layanan bimbingan konseling terhadap etika pergaulan siswa kelas 5 SD N 1 Kebumen 2019/2020 yang berjumlah 39 siswa. Penelitian ini menggunakan pendekatan deskriptif kuantitatif dengan metode survey pembagian jenis angket tertutup yang didalamnya terdapat alternatif jawaban berupa "Ya" atau "Tidak" serta pendekatan deskriptif kualitatif dengan metode pengumpulan data berupa wawancara kepada guru untuk memperoleh keterangan lebih lanjut. Indikator penelitian etika pergaulan meliputi sopan santun, empati, suasana dan tempat bergaul, kejujuran serta ketertiban. Data yang terkumpul dianalisis menggunakan analisis prosentase. Hasil penelitian menunjukkan bahwa etika pergaulan siswa tergolong dalam kriteria sangat tinggi dengan prosentase 87,17\% (34 siswa) sedangkan kriteria tinggi sebanyak 12,8\% (5 siswa). Simpulan penelitian ini adalah ketrampilan etika pergaulan siswa tergolong baik dikarenakan prosentase hasil penelitian terhitung tinggi dan hasil wawancara dengan wali kelas mengenenai layanan BK tergolong efektif . Sehubungan dengan penelitian ini, layanan bimbingan konseling berpengaruh terhadap tingkat etika pergaulan pada siswa.
\end{abstract}

Kata kunci: etika, pergaulan, layanan Bimbingan Konseling

Social, Humanities, and Education Studies (SHEs): Conference Series https://jurnal.uns.ac.id/shes

p-ISSN 2620-9284

e-ISSN 2620-9292 


\section{PENDAHULUAN}

Masalah etika, adalah masalah manusia dimanapun manusia berada dalam komunitasnya, pasti etika ikut berperan sebagai pedoman tingkah laku baik - buruk dalam pergaulan sesama mereka. Etika menurut kamus besar bahasa Indonesia mengandung arti: (a) ilmu tentang apa yang baik dan apa yang buruk tentang hak dan kewajiban moral; (b) kumpulan azas atau nilai yang berkenaan dengan akhlak; (c) nilai mengenai benar dan salah yang dianut suatu golongan atau masyarakat. Sesuai pendapat Sri Hudiarini, etika adalah sebuah pengertian tentang salah dan benar, atau buruk dan baik.

Adapun menurut Maidiantius Tanyid, etika pada hakikatnya mengamati realitas moral secara kritis dan dalam kajian secara terminologi, etika berarti sebuah cabang ilmu yang membicarakan perbuatan atau tingkah laku manusia dalam hubungannya dengan yang baik dan yang buruk.

Sedangkan menurut Bertens ada dua pengertian etika: sebagai praktis dan sebagai refleksi. Sebagai praktis, etika berarti nilai-nilai dan norma-norma moral yang baik yang dipraktikkan atau justru tidak dipraktikkan, walaupun seharusnya dipraktikkan. Etika sebagai praktis sama artinya dengan moral atau moralitas yaitu apa yang harus dilakukan, tidak boleh dilakukan, pantas dilakukan, dan sebagainya. Etika sebagai refleksi adalah pemikiran moral. Jadi etika adalah peraturan mengenai sikap atau kebiasaan yang sesuai dengan norma-norma masyarakat.

Pergaulan adalah istilah yang digunakan untuk menjelaskan tentang segala hal yang berhubungan dengan orang lain. Dalam KBBI menerangkan bahwa kata pergaulan berasal dari "Gaul" yang berarti hal bergaul. Sedangkan kata pergaulan memiliki arti: "hal bergaul atau kehidupan bermasyarakat". Menurut Rosady Ruslan, dalam pergaulan hidup terdapat empat kaidah atau norma, yaitu norma agama, kesusilaan, kesopanan dan hukum. Dalam pelaksanaannya, norma terbagi lagi menjadi norma-norma umum (non hukum) dan norma hukum. Pemberlakuan normanorma itu dalam aspek kehidupan dapat digolongkan menjadi dua macam kaidah sebagai berikut:

1. Aspek kehidupan pribadi (individual), meliputi:

a. Kaidah kepercayaan untuk mencapai kesucian hidup pribadi atau kehidupan yang beriman.

b. Kehidupan kesusilaan, nilai moral dan etika yang tertuju pada kebaikan hidup pribadi demi tercapainya kesucian hati nurani yang berakhlak berbudi luhur.

2. Aspek kehidupan antar pribadi (bermasyarakat), meliputi:

a. Kaidah atau norma-norma sopan-santun, tata karma, dan etiket dalam pergaulan sehari;hari dan bermasyarakat ( pleasant living together).

b. Kaidah-kaidah hukum yang tertuju pada terciptanya ketertiban, kedamaian, dan keadilan dalam kehidupan bersama atau bermasyarakat yang penuh dengan kepastian atau ketentraman (peaceful living together).

Menurut Swardi Endraswara (2010 :75-76), dalam pergaulan sehari-hari di sekolah siswa hendaknya:

1. Mengucapkan salam terhadap teman, guru, kepala sekolah dan pegawai sekolah apabila baru bertemu pada waktu pagi hari, siang hari dan atau akan berpisah pada siang dan sore hari. Melaksanakan 5 S (sapa, senyum, salam, sopan dan santun).

2. Menghormati sesama siswa, saling menyayangi, menghargai perbedaan agama yang dianut dan latar belakang sosial budaya yang dimiliki oleh masing-masing teman baik di sekolah maupun di luar sekolah.

3. Menghormati ide, pikiran dan pendapat, hak cipta orang lain dan hak milik teman dan warga sekolah.

4. Berani menyampaikan sesuatu yang salah adalah salah dan menyatakan sesuatu yang benar adalah benar. 
5. Menyampaikan pendapat secara sopan dan tidak menyinggung perasaan orang lain.

6. Membiasakan diri mengucapkan terima kasih kalau memperoleh bantuan atau jasa dari orang lain.

7. Berani mengaku kesalahan yang terlanjur telah dilakukan dan meminta maaf apabila merasa melanggar hak orang lain atau berbuat salah kepada orang lain.

8. Menggunakan bahasa (kata) yang sopan dan beradap yang membedakan hubungan dengan orang lain yang lebih tua dan teman sejawat, dan tidak menggunakan kata-kata kotor dan kasar, cacian dan pornografi.

Etika diperoleh melaui peran lingkungan keluarga, pendidikan dan masyarakat. Dalam lingkungan keluarga etika ditanamkan oleh orang tua, dimana pendidikan moral paling utama berasal dari lingkungan keluarga. Etika juga ditanamkan dalam lingkungan pendidikan dan lingkungan masyarakat. Dalam bergaul, atau bersosialisasi dilingkungan sekitar, sebagai makhluk sosial harus memiliki etika bergaul yang baik dan sehat. Untuk itu diperlukan kedisiplinan menurut Leli Siti Hadianti (2008) yang menyatakan, kedisiplinan merupakan kepatuhan mentaati peraturan dan ketentuan yang telah ditetapkan. Etika pergaulan merupakan suatu hal yang mencerminkan moral yang harus dipahami oleh semua orang yang berada dalam lingkungan sosial dan lingkungan pendidikan (sekolah), karena di manapun dan kapanpun seseorang selalu diperhadapkan dengan orang-orang yang ada di sekitar, dan apabila tidak menyadari dan memahami situasi yang ada di sekitarnya maka bisa saja akan melakukan suatu hal yang melanggar norma-norma yang berlaku dalam lingkungan tersebut atau pada kelompok-kelompok tertentu.

Sekarang ini, norma dan etika dilingkungan sekitar kurang diperhatikan dan mengalami penurunan. Secara spesifik penurunan etika pergaulan dipengaruhi oleh dua faktor yaitu faktor internal dan eksternal:

Faktor internal dipengaruhi oleh tingkat perkembangan intelektual, atau faktor yang timbul dari diri seseorang akibat kelalaian dan kemalasan untuk mendalami nilainilai kemoralan. Etika yang seharusnya diutamakan malah dilupakan dan diabaikan seakan etika menjadi hal tabu. Faktor eksternal berupa pengaruh dari orang tua, kelompok sebaya, masyarakat, media masa, walaupun faktor ini muncul dari luar kepribadian seseorang namun sangat dominan merubah karakter. Karena dari melihat, mencoba dan terbiasa, sikap pribadi seseorang akan berubah seketika. Faktor eksternal yang muncul dari keluarga yang kurang empati terhadap pendidikan beretika, keluarga tidak terlalu memperhatikan masa depan moral anak. Contohnya, terjadi dilingkungan sekolah zaman dulu, para pelajar sangat takut untuk lewat atau berpapasan dengan guru dan memilih untuk melewati jalan lain, tapi lain halnya dengan pelajar zaman sekarang, biarpun ada guru meraka santai saja lewat, menunduk badan sedikitpun tidak.

Sebab itu penting untuk menanamkan pemahaman kepada siswa mengenai etika pergaulan agar mereka mampu mengaplikasikan di dalam kehidupannya. Jika hal ini dianggap sepele, maka secara tidak langsung akan membiarkan siswa menjadi tidak terkontrol, bahkan tingkat penghargaan terhadap guru akan sangat minim. Etika dalam pergaulan perlu diajarkan kepada siswa agar mereka memahami dan menerapkannya di lingkungan sekolah atau bahkan di lingkungan secara menyeluruh, misalkan etika berbicara dan bertindak.

Oleh karena itu layanan bimbingan konseling di sekolah sangat diperlukan sebagai pencegahan dan perbaikan perilaku etika negatif agar peserta didik memiliki etika pergaulan yang baik terutama dalam lingkungan keluarga, teman sebaya, sekolah maupun masyarakat. Sehingga tercipta generasi yang bermoral dan beretika baik yakni memiliki sopan santun, empati, jujur, tertib, disiplin dan mampu beradaptasi dalam bergaul. 


\section{METODE}

Metode penelitian ini menggunakan pendekatan deskriptif kuantitatif dengan metode survey melalui pembagian angket tertutup yang terdapat alternatif jawaban berupa "Ya" atau "Tidak" serta pendekatan deskriptif kualitatif dengan metode pengumpulan data berupa wawancara kepada guru kelas untuk memperoleh keterangan lebih lanjut untuk tujuan penelitian.

Untuk mengetahui valid atau tidak maka dilakukan uji validitas dengan menggunakan rumus korelasi product moment sebagai berikut:

$$
\begin{aligned}
r_{x y}=\frac{N \sum X Y-\left(\sum X\right)\left(\sum Y\right)}{\sqrt{\left\{N \sum X^{2}-\left(\sum X\right)^{2}\right\}\left\{N \sum Y^{2}-\left(\sum Y\right)^{2}\right\}}} \quad & \text { Keterangan: } \\
& r_{x y}=\text { Koefisien korelasi } \\
& \mathrm{X}=\text { Skor butir } \\
& \mathrm{Y}=\text { Skor total } \\
& \mathrm{N}=\text { Skor subyek } \\
& \text { (Suharsimi Arikunto, 2006:168) }
\end{aligned}
$$

Pengelolahan data masing-masing item dibandingkan dengan $r$ tabel, dengan kriteria sebagai berikut:

a)Apabila $r$ hitung $>r$ tabel (pada tarif signifikansi 5\%) dikatakan item kuesioner valid.

b)Apabila $r$ hitung $<r$ tabel (pada tarif signifikansi 5\%) dikatakan item kuesioner tidak valid.

Validitas dalam instrumen skala ketrampilan etika pergaulan menggunakan rumus "Korelasi Product Moment" dengan taraf signifikan 5\% dan jumlah subjek 39 siswa, sehingga diperoleh $r$ tabel sebesar 0,316.

Analisis yang digunakan adalah analisis data deskriptif prosentase. Dengan rumus:

\begin{tabular}{cc}
$\%=\frac{n}{N} \times 100 \%$ & $\begin{array}{l}\text { Keterangan: } \\
\%: \text { Nilai presentase } \\
\\
n \text { : Jumlah skor yang diperoleh } \\
N\end{array}$ \\
& $\begin{array}{c}N \text { Jumlah skor total (Sudjana, 2005:47) } \\
\text { Kriteria Penilaian Tingkat Etika Pergaulan Siswa }\end{array}$ \\
\hline presentase & kriteria \\
\hline $84 \%-100 \%$ & Sangat tinggi \\
$68 \%-83 \%$ & Tinggi \\
$52 \%-67 \%$ & Sedang \\
$36 \%-51 \%$ & Rendah \\
$20 \%-35 \%$ & Sangat rendah \\
\hline
\end{tabular}

\section{HASIL DAN PEMBAHASAN}

Bab ini akan menguraikan dan membahas hasil penelitian berupa pengisisan angket dan wawancara pada wali kelas V SD Negeri 1 Kebumen yang telah dilaksanakan pada hari Kamis, 12 September 2019 dengan jumlah responden sebanyak 39 siswa. Untuk itu,akan kami jelaskan melalui grafik yang menggambarkan keterampilan etika pergaulan siswa SD N 1 Kebumen kelas V. Berikut adalah persentase keseluruhan dari hasil penelitian:

\section{a. Aspek Kesopanan}

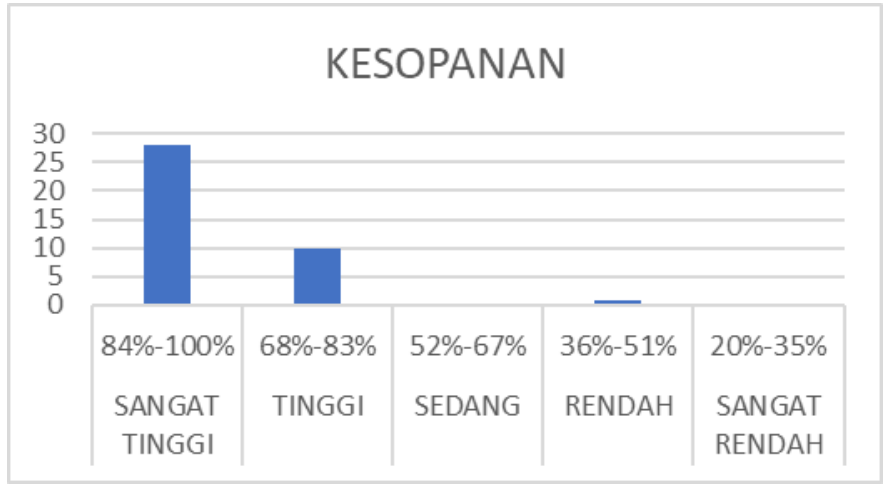


Berdasarkan grafik diatas dapat diketahui bahwa sebagian besar responden yaitu sebanyak 28 responden memiliki etika pergaulan dengan aspek kesopanan yang sangat tinggi di tinjau dari hasil penelitian, siswa menunjukan sikap $5 \mathrm{~S}$ (senyum, salam, sapa, sopan, santun), selalu mengucapkan terimakasih, dan tidak memanggil teman dengan kata-kata yang tidak baik. Sebanyak 10 responden memiliki tingkat kesopanan yang tinggi ditinjau dari hasil penelitian, sebagian besar responden kurang menerapkan sikap 5S. Sedangkan sebanyak 1 responden memiliki tingkat kesopanan yang rendah di tinjau dari hasil penelitian, responden tersebut tidak menerapkan 5S dan bersikap acuh terhadap lawan bicaranya. Hasil tersebut sesuai dengan pendapat Suwardi Endaswara (2010) yang menyatakan bahwa siswa sekolah hendaknya mengucaokan salam terhadap teman, guru, kepala sekolah, dan pegawai sekolah apabila baru bertemu pada waktu pagi, siang hari, dan atau akan berpisah pada siang dan sore hari. Melaksanakan 5S (sapa, senyum, salam, sopan, dan santun). Serta menggunakan Bahasa (kata) yang sopan dan beradab yang membedakan hubungan dengan orang lain yang lebih tua dan teman sejawat, dan tidak menggunakan katakata kotor dan kasar, cacian dan pornografi.

\section{b. Aspek Empati}

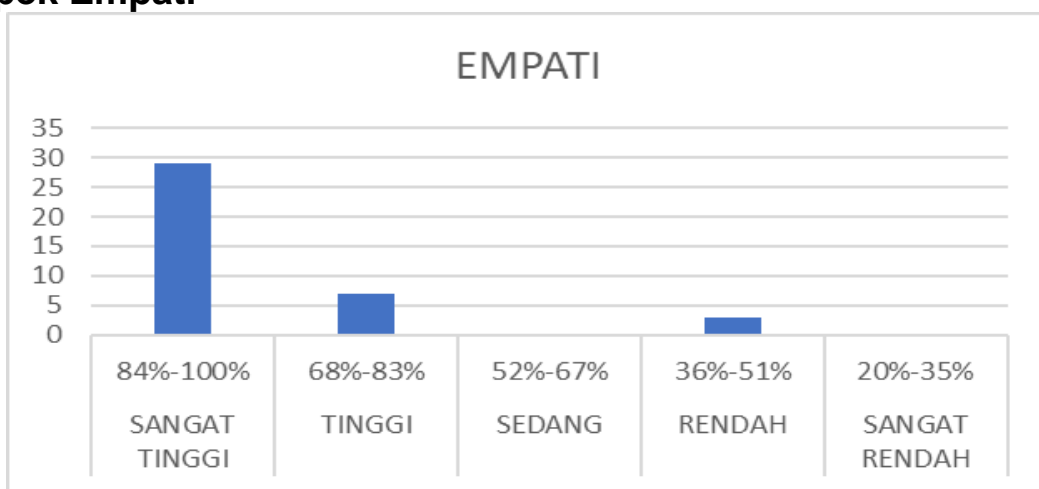

Berdasarkan grafik diatas dapat diketahui bahwa sebagian besar responden yaitu sebanyak 29 responden memiliki empati yang sangat tinggi di tinjau dari hasil penelitian, responden memiliki rasa peduli yang tinggi dan tidak segan meminta maaf. Sebanyak 7 responden memiliki empati yang tinggi di tinjau dari hasil penelitian, responden memiliki rasa peduli yang tinggi namun masih memiliki rasa segan untuk meminta maaf. Dan sebanyak 3 responden memiliki empati yang rendah di tinjau dari hasil penelitian, responden segan meminta maaf dengan teman meskipun berbuat kesalahan. Hasil ini sejalan dengan pendapat Suwardi Endaswara (2010), bahwa siswa hendaknya menghormati sesame siswa, saling menyayangi, menghargai perbedaan agama yang dianut dan latar belakang social budaya yang dimiliki oleh masing-masing teman baik di sekolah maupun di luar sekolah. Serta berani mengakui kesalahan yang terlanjur telah dilakukan dan meminta maaf apabila merasa melanggar hak orang lain atau berbuat salah pada orang lain.

\section{c. Aspek Suasana dan Tempat}

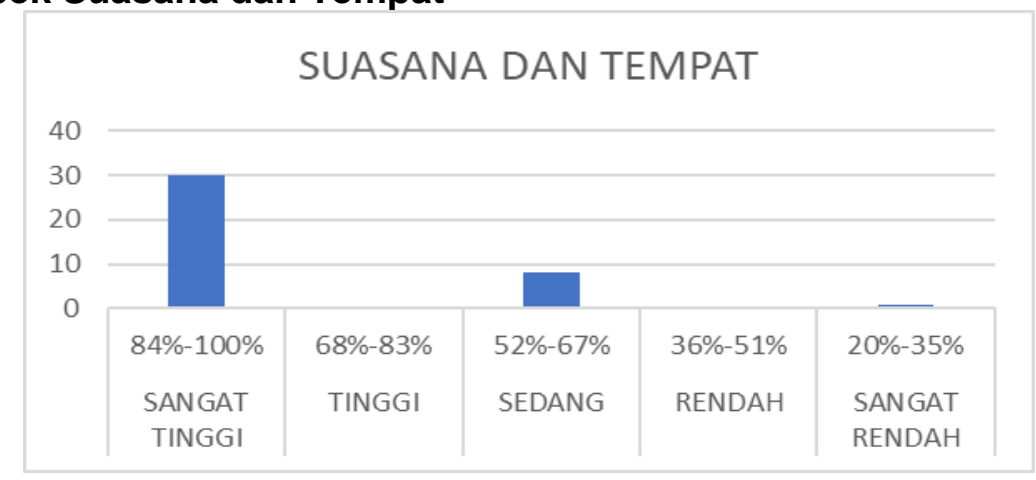


Berdasarkan grafik diatas dapat diketahui bahwa sebagian besar responden yaitu sebanyak 30 responden dengan kategori sangat baik atau sangat tinggi di tinjau dari hasil penelitian, responden tidak terpengaruh dengan trend pergaulan yang kurang baik dan bisa memposisikan pergaulannya pada suasana dan tempat dengan baik. Sebanyak 8 dengan kategori sedang di tinjau dari hasil penelitian, responden tidak terpengaruh dengan trend pergaulan yang kurang baik, namun kurang bisa memposisikan pergaulan pada suasana dan tempat. Dan 1 responden dengan kategori sangat rendah di tinjau dari hasil penelitian, responden masih terpengaruh dengan tren pergaulan yang kurang baik dan kurang bias memposisikan pergaulan pada suasana dan tempat. Hasil tersebut sesuai dengan.

\section{d. Aspek Kejujuran}

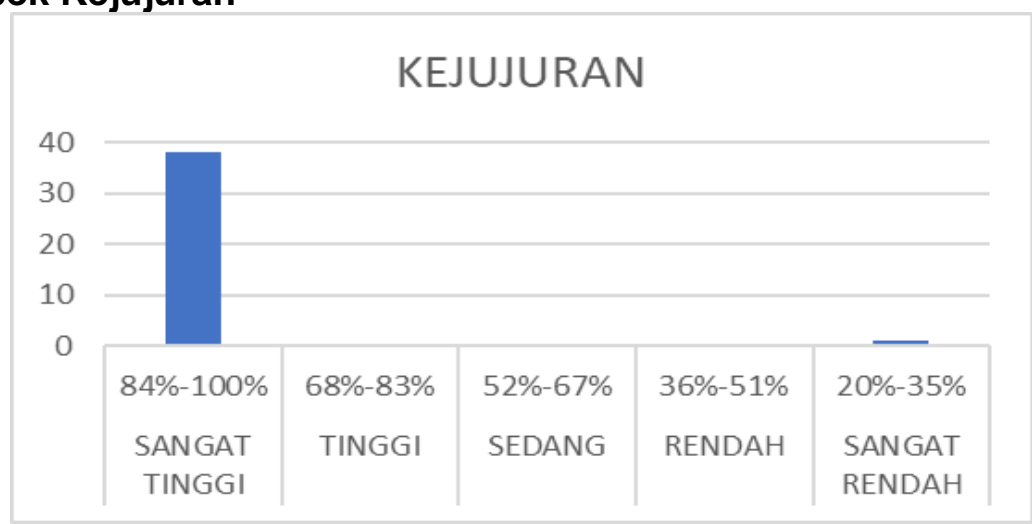

Berdasarkan grafik diatas dapat diketahui bahwa sebagian besar responden yaitu sebanyak 38 responden memiliki tingkat kejujuran dalam bergaul yang sangat tinggi di tinjau dari hasil pengisian angket responden jujur dalam meminjam atau pun mengembalikan barang milik orang lain dan tidak mencontek saat ujian. Sedangkan 1 responden memiliki tingkat kejujuran dalam bergaul yang sangat rendah di tinjau dari hasil pengisian angket responden tidak mencotek saat ujian namun tidak jujur dalam meminjam maupun mengembalikkan barang milik orang lain. Hasil ini sejalan dengan pendapat Suwardi Endaswara (2010), bahwa siswa hendaknya berani menyampaikan sesuatu yang salah adalah salah,dan menyatakan sesuatu yang benar adalah benar.

\section{e. Tertib dan Disiplin}

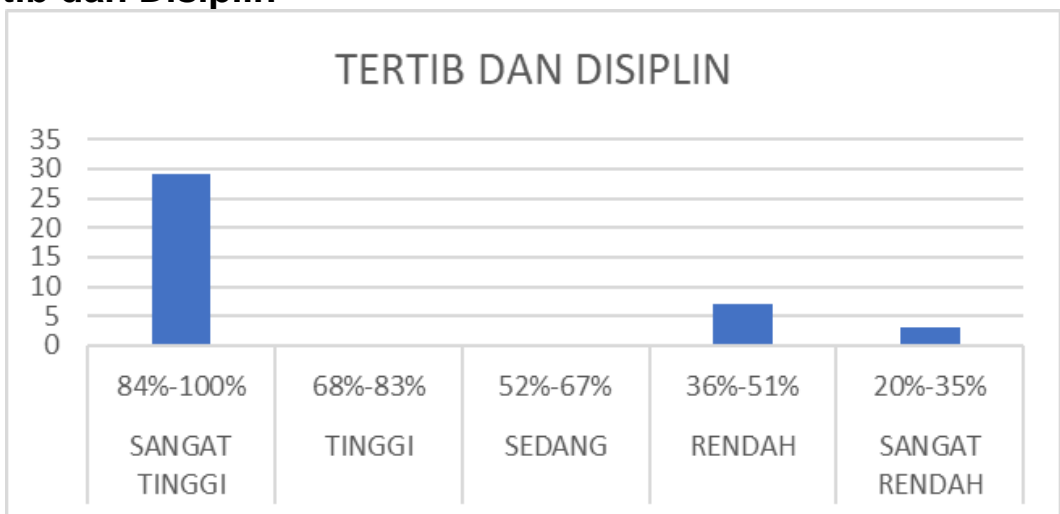

Berdasarkan grafik diatas dapat diketahui bahwa sebagian besar responden yaitu sebanyak 29 responden memiliki tingkat ketertiban dan kedisiplinan dalam bergaul sangat tinggi di tinjau dari hasil penelitian, responden selalu berangkat sekolah dan mengumpulkan tugas tepat waktu. Sebanyak 7 responden memiliki tingkat ketertiban dan kedisiplinan dalam bergaul yang rendah di tinjau dari hasil penelitian, responden mengumpulkan tugas tepat waktu namun sering telat jika berangkat sekolah. Dan sebanyak 3 responden memiliki tingkat ketertiban dan kedisiplinan dalam bergaul yang sangat rendah di tinjau dari hasil penelitian, responden tidak tepat waktu 
berangkat sekolah dan mengumpulkan tugas. Hal ini sesuai dengan pedapat Leli Siti Hadianti (2008) yang menyatakan bahwa, kedisiplinan merupakan kepatuhan mentaati peraturan dan ketentuanyang telah ditetapkan.

Dari data yang diperoleh di atas juga didukung dengan hasil wawancara kepada guru wali kelas, sehingga diperoleh informasi bahwa di SD N 1 Kebumen terdapat layanan bimbingan konseling namun tidak berupa mata pelajaran namun berbentuk layanan yang dilaksanakan ketika ada masalah. Bimbingan konseling di SD N 1 Kebumen ditangani secara langsung oleh wali kelas setiap kelasnya.layanan bimbingan konseling berpengaruh langsung terhadap etika pergaulan siswa kelas $\mathrm{V}$. Berdasarkan informasi yang telah diperoleh dari guru kelas, rata-rata siswa kelas $\mathrm{V}$ memiliki etika pergaulan yang baik ditinjau dari aspek kesopanan, empati, suasana dan tempat pergaulan, kejujuran dan tertib serta disiplin.

\section{SIMPULAN}

Berdasarkan hasil penelitian dan pembahasan, maka dapat disimpulkan bahwa layanan bimbingan konseling mempengaruhi etika pergaulan siswa kelas V SD Negeri 1 Kebumen. Layanan bimbingan konseling yang diberikan oleh wali kelas meliputi bimbingan belajar, bimbingan pribadi, serta bimbingan cita-cita,.. Sehingga diperoleh hasil dari pengisian angket dan wawancara pada wali kelas $\mathrm{V}$ yang menunjukan siswa memiliki tingkat kesopanan, empati, suasana dan tempat, kejujuran, tertib dan disiplin yang tinggi Pengisian angket pada siswa mencapai presentase rata-rata $84-100 \%$.

\section{DAFTAR PUSTAKA}

Arikunto, S. (2006). Prosedur Penelitian suatu Pendekatan Praktik. Jakarta: PT Rineka Cipta.

Bertens, K. (2013). Etika (Edisi Revisi). Yogyakarta: Kanisius.

Endaswara, S. (2010). Etika Hidup Orang Jawa. Yogyakarta: Narasi.

Hadianti, L.S. (2008). Pengaruh Pelaksanaan Tata Tertib Sekolah Terhadao Kedisiplinan Belajar Siswa (Penelitian Deskriftif Analisis di SD N Sukakarya II Kecamatan Semarang Kabupaten Garut). Jurnal Pendidikan Universitas Garut.

Hudiarini, S. (2017). Penyertaan Etika bagi Masyarakat Akademik di Kalangan Dunia Pendidikan Tinggi. Jurnal Moral Kemasyarakatan. Vol. 2, No. 1.

KBBI. (2016). Kamus Besar Bahasa Indonesia (KBBI). [Online]. Tersedia di http://kbbi.web.id/etika. Diakses 18 September 2019.

KBBI. (2016). Kamus Besar Bahasa Indonesia (KBBI). [Online]. Tersedia di http://kbbi.web.id/prergaulan. Diakses 18 September 2019.

Ruslan, R. (2008). Etika Kehumasan Konsepsi dan Aplikasi. Jakarta: PT Raja Grafindo Persada.

Sudjana. (2005). Metode Statistika. Bandung: Tarsito.

Tanyid, M. (2014). Etika dalam Pendidikan: Kajian Etis tentang Krisis Moral Berdampak pada Pendidikan. Jurnal JAFFRAY, Vol.12 No.02. 